\title{
Platinum-based Regimens in First-line Therapy of Non-Small Cell Lung Cancer
}

\section{Küçük Hücreli Dışı Akciğer Kanserinde Birinci Basamak Tedavide Platin Bazlı Rejimler}

\author{
Abdulkadir Karışmaz ${ }^{1}$, Mustafa Sevinc ${ }^{2}$, Murat Tugcu ${ }^{3}$, Fuat Hulusi Demirelli ${ }^{4}$, Hande Turna ${ }^{4}$ \\ ${ }^{1}$ Sağlık Bilimleri Üniversitesi, İstanbul Eğitim Ve Araştırma Hastanesi, Hematoloji Bölümü, İstanbul \\ ${ }^{2}$ Şişli Hamidiye Etfal Eğitim Ve Araştırma Hastanesi, Nefroloji Bölümü, İstanbul \\ ${ }^{3}$ Marmara Üniversitesi Pendik Eğitim Ve Araştırma Hastanesi, Nefroloji Bilim Dalı, İstanbul \\ ${ }^{4}$ İstanbul Üniversitesi-cerrahpaşa, Cerrahpaşa Tıp Fakültesi, Onkoloji Bilim Dalı, İstanbul
}

\section{ÖZET}

GİRIŞ ve AMAÇ: Akciğer kanseri hem erkek hem de kadınlarda kansere bağlı ölüm nedenleri arasında ilk sırada yer almaktadır. Metastatik KHDAK (küçük hücreli dışı akciğer kanseri) hastalarında günümüzde EGFR, ALK ve ROS1 mutasyonu yoksa standart tedavi platin bazlı bir kombinasyon rejimidir. Platinin yanına kombine edilen ajanın seçimi genellikle ilacın toksisite profili ve hastanın toleransı göz önüne alınarak belirlenmektedir. Bu çalışmada metastatik KHDAK tanısı almış olgularda farklı histolojik alt tiplere göre uygulanan birinci seri sistemik kemoterapi ile elde edilen yanıt oranlarını, progresyonsuz sağkalım ve genel sağkalım sürelerini belirlemeyi amaçladık.

YÖNTEM ve GEREÇLER: Çalışmaya Cerrahpaşa Tıp Fakültesi Medikal Onkoloji BD’na 2005-2010 yılları arasında başvuran, evre IV KHDAK tanılı 300 hasta alınmıştır. Hastaların dosyaları retrospektif olarak taranarak hastaların demografik özellikleri, sigara içme durumu, tümör tipi, birinci seride uygulanan kemoterapi tipi, tedavi yanıt oranları, progresyona kadar geçen zaman ve genel sağkalım süreleri belirlendi. BULGULAR: Birinci seri kemoterapi sonrası progresyona kadar geçen süre ortalama 5 hafta (GA: 4.5-5.5 ) olarak saptandı. Tüm histopatolojik tipler açısından progresyona kadar geçen süreler değerlendirildiğinde birinci seride kullanılan 5 temel ilaç grubu arasında sadece sisplatin-dosetaksel kombinasyonu ile sisplatin-gemsitabin kombinasyonu arasındaki fark istatistiksel olarak anlamlı bulundu ( $\mathrm{p}=0.03)$. Skuamöz hücreli karsinomlarda birinci seride kullanılan 5 ana ilaç grubu arasında progresyona kadar geçen süre açısından istatistiksel olarak anlamlı bir fark saptanmadı. Adenokarsinom alt tipi için birinci seride kullanılan 5 ana ilaç grubu arasında progresyona kadar geçen süre açısından bakıldığında sadece sisplatin-dosetaksel ve sisplatin- gemsitabin kombinasyonu arasında sisplatin - dosetaksel lehine istatistiksel olarak anlamlı bir üstünlük saptandı. TARTIŞMA ve SONUÇ: Günümüzde Evre 4 KHDAK tedavisinde moleküler testleri değerlendirmekteyiz. Eğer EGFR, ALK ve ROS 1 mutasyonu yoksa sistemik sitotoksik kemoterapi rejimlerini kullanmaktayı. Bu rejimler de platin bazlı rejimler olmaktadır. Platin yanına ilk basamakta verilecek ajanların progresyona kadar geçen süre göz önüne alındığında skuamöz hücreli kanserde rejimler arasında bir fark saptanmamıştır. Adenokarsinomda ise sisplatin - dosetaksel kombinasyonu daha etkin saptanmıştır.

Anahtar Kelimeler: Akciğer Kanseri, Platin Bazlı Rejimler, Tedavi Yanıtı

\begin{abstract}
INTRODUCTION: Lung cancer is the leading cause of cancer-related death in both men and women. If there is no EGFR, ALK and ROS1 mutation in patients with metastatic NSCLC (non-small cell lung cancer), the standard treatment is a platinum-based combination regimen. The choice of agent combined with platinum is generally determined by considering the toxicity profile of the drug and the tolerance of the patient. In this study, we aimed to determine the response rates, progression-free survival and overall survival in patients with metastatic NSCLC with first-line systemic chemotherapy according to different histological subtypes. MATERIAL AND METHODS: The files of totally 300 patients 62 of whom were female and followed with the diagnosis of Stage IV Non-Small Cell Lung Cancer in the Clinic of Medical Oncology of Cerrahpaşa Medical Faculty were investigated retrospectively between 2005 and 2010. Types of first line chemotherapy, the number of cures, treatment response rates, time to progression and overall survival times were determined. RESULTS: Median time to progression after first line chemotherapy for all the cases was detected as 5 weeks. In the cases with squamous cell cancer, no significant superiority was detected in terms of time to progression
\end{abstract}


with different regimens. In the cases with adenocarcinoma, Cisplatin-Docetaxel combination was found to provide a significant superiority to the Cisplatin-Gemcitabine combination in terms of time to progression. DISCUSSION AND CONCLUSION: We are currently evaluating molecular tests for the treatment of stage 4 NSCLC. If there is no EGFR, ALK and ROS 1 mutation, we use systemic cytotoxic chemotherapy regimens. These regimens are platinum-based. There was no difference between the regimens in squamous cell carcinoma when the time to progression of the agents to be given to platinum first step was taken into consideration. Cisplatin - docetaxel combination was found to be more effective in adenocarcinoma.

Keywords: Lung Cancer, Platinum-based Regimens, Treatment Response

\section{GİRİŞ ve AMAÇ}

Akciğer kanseri hem erkek hem de kadınlarda kansere bağlı ölüm nedenleri arasında ilk sırada yer almaktadır (1). Küçük hücreli dış1 akciğer kanseri (KHDAK) tedavisi hastalığın evresine göre değişim göstermektedir. Evre I ve Evre II'de ana tedavi yöntemi cerrahidir. Cerrahi sonrası evre II hastalara 4 siklus adjuvan sisplatin bazlı kemoterapi verilmesi önerilmektedir. Evre I hastalıkta ise cerrahi sonrası yüksek risk faktörlerinin varlığında kemoterapi önerilebilmektedir. Lokal ileri evre olarak adlandırılan evre III hastalıkta ise, ana tedavi yöntemi eş zamanlı kemoradyoterapi verilmesidir. Seçilmiş evre III hastalarda tedaviye cerrahi eklenebilir. Evre IV hastalıkta ana tedavi yöntemi sistemik tedavidir ve tedavi seçimi histolojik alt tip ve tümörde saptanan mutasyonlara göre kişiselleştirilir $(2,3)$.

Yakın geçmişe değin, akciğer kanseri tedavisi, hastalığın evresine göre değişen planlarla cerrahi, radyoterapi ve kemoterapi seçeneklerinin tek veya farklı kombinasyonlarda uygulanmasinı içermekteydi. Son yillarda hücre siklus kontrolü, metastatik süreç ve immün hücretümör etkileşimi konusundaki bilgilerin artmasıyla, özellikle ileri evre olgularda çeşitli tedavi seçeneklerin geliştirilmesi imkanları kazanıldı. Bu noktada, hastanın sahip olduğu bazı genetik özellikler tedavide kullanılacak ajan tercihinde yönlendirici olabilmektedir. Kişiye özel tedavi programları için en etkin biyobelirteç, onkojenik sürücü mutasyon olarak isimlendirilen somatik genlerdeki değişikliklerdir. Tüm ileri evre hastalarda, adenokarsinom komponenti olan mikst tümör tanıs1 alan hastalarda cinsiyet, sigara öyküsü, ırk veya diğer klinik özelliklere bakılmaksızın epidermal growth faktör reseptör (EGFR), anaplastic lymphoma kinase (ALK), c-ROS oncogene 1 reseptor tyrozin kinase (ROS1) gibi mutasyon analizleri yapılmakta, yine küçük biyopsi örneğinde adenokarsinom komponenti dışlanamayacağı için, skuamöz ve küçük hücreli karsinom histolojisine rağmen hasta genç ve sigara içmemişse, bu hastalarda da mutasyon analizleri istenmektedir. Hedeflenebilir mutasyon saptanan olgularda bir çok alternatif ilaç ile sağkalım avantajı sınırlı sürelerle de olsa sağlanabilmektedir $(2,3)$. Akciğer kanser tedavisi ile ilişkili son gelişme immün kontrol nokta inhibitörlerinin, programlı hücre ölümü (PD- L1; programmed cell death 1/ ligand 1) veya sitotoksik Tlenfosit ilişkili protein 4 (CTLA4) tedavi seçeneğinin tanımlanması üzerine olmuştur (4).

Bu çalışmanın amacı 2005-2010 yılları arasında metastatik KHDAK tanısı almış olgularda farklı histolojik alt tiplere göre uygulanan birinci seri sistemik kemoterepi ile elde edilen yanit oranlarını, progresyonsuz sağkalım ve genel sağkalım sürelerini belirleyebilmektir.

\section{MATERYAL - METOD}

$\mathrm{Bu}$ çalışmaya Cerrahpaşa Tip Fakültesi Medikal Onkoloji Bilim Dalı Polikliniğinde 01.01.2005-01.09.2010 tarihleri arasinda takip edilen hastalardan dosyasına ulaşılabilen Evre IV Küçük Hücreli Dışı Akciğer Kanseri tanısı almış 62'si kadın toplam 300 hasta alınmıştır.

\section{BULGULAR}

Olguların 234'ü (\%78) ilk seride 4 ve daha fazla kur kemoterapi alırken, 66's1 (\%22) 3 ve daha az sayıda kemoterapi almıştır. Olguların birinci seri tedavide aldığ 1 kemoterapiler tablo 1 'de özetlenmiştir. İlk seri kemoterapi sonrası yapılan radyolojik değerlendirmede hastaların 82'si $(\% 27,3)$ stabil, 136's1 (\%45,3) progrese, 29'u kısmi yanitlı, 2'si $(\% 0,7)$ tam yanitl kabul edildi.51 hastada (\%17) radyolojik 
kontrol sonras1 değerlendirme yapılamadi. Hastaların 175'i bir seri, 116'sı iki seri, 8'i üç seri, 1'i 4 seri kemoterapi almıştı.Íkinci seride olguların 99'u tek ajan kemoterapisi, 27'si kombine kemoterapi tedavisi ald1.174 hastada ikinci seri kemoterapi verilmedi. Hastaların genel sağkalım süresi ortanca 13ay \pm 0.6 (GA: 11.9-14.2 ) olarak saptanmıştır. Tüm hastalar için genel sağkalım süresi 1 numaralı grafikte izlenmektedir. Erkek ve kadınlar arasında genel sağkalım süreleri açısından istatistiksel olarak anlamlı bir fark saptanmamıştır ( $\mathrm{p}=0.097)$ Histolojik alt tiplere göre ortanca sağkalım süreleri aşağıdaki grafikte görülmektedir. Skuamöz Hücreli karsinom için $14 \pm 0.9$ ay (GA:12.2-15.8), adenokarsinom için $12 \pm 0.7$ ay (GA:10.6-13.4), büyük hücreli

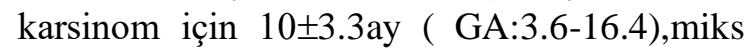

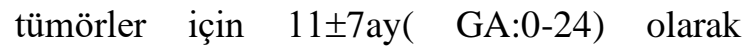
saptanmıştır. (Grafik:1) Birinci seri kemoterapi sonrası progresyona kadar geçen süre ortanca 5 \pm 0.3 hafta (GA:4.5-5.5 ) olarak saptanmıştır. Tüm olgular için birinci seri kemoterapi sonras1 progresyona kadar geçen süre 2 numaralı grafikte izlenmektedir. Birinci seri kemoterapi sonras1 ortanca progresyona kadar geçen süre histolojik alt tiplere göre değerlendirildiğinde skuamöz hücreli karsinom için $4 \pm 0.4$ hafta (GA:3.1-4.9),adenokarsinom için 5 5 .5hafta (GA:4.1-5.9),büyük hücreli karsinom için $7 \pm 4.4$ hafta(GA:0-15.6), miks tümörler için $8 \pm 0.9$ hafta (6.3-9.7) olarak saptanmıştır. Birinci seri kemoterapi sonras1 histopatolojik alt tiplere göre progresyona kadar geçen süre 3 numaralı grafikte görülmektedir. Birinci seri kemoterapi sonras1 progresyona kadar geçen süre histolojik alt tipler açısından değerlendirildiğinde farklı histolojik alt tipler arasında istatistiksel bir anlamlılık saptanmad $(\mathrm{p}=0.083)$ Progresyona kadar geçen süre Cispaltin-Etoposid için 8.5 \pm 3.8 hafta (GA:0.9-16), Cisplatin-Gemsitabin için 6.0 \pm 0.5 hafta (GA:5.1-7.0), CisplatinDosetaksel için 8.7 \pm 1.3 hafta (GA:6.2-11.2), Carboplatin-Taksan için 5.8 \pm 0.7 (GA:4.4-7.3), Cisplatin-Vinorelbin için 8.5 \pm 1.9 (GA:5.9-7.8 ) olarak saptanmıştır.Tüm histopatolojik tipler açısından progresyona kadar geçen süreler değerlendirildiğinde birinci seride kullanılan ilaç grubu arasında sadece CisplatinDosetaksel kombinasyonu ile CisplatinGemsitabin kombinasyonu arasındaki fark istatistiksel olarak anlamlı bulunmuştur $(\mathrm{p}=0.03) \quad$ Birinci seri kemoterapinin olgularımızın iki major grubu olan skuamöz ve adenokarsinom tiplerinde sağladığ progresyona kadar geçen süreler belirlendi. Skuamöz hücreli karsinomlarda birinci seride kullanılan 5 ana ilaç grubu arasında progresyona kadar geçen süre açısından istatistiksel olarak anlaml bir fark saptanmamıştır $(\mathrm{p}=0.067)$ Adenokarsinom alt tipi için birinci seride kullanılan 5 ana ilaç grubu arasında progresyona kadar geçen süre açısından bakıldığında sadece CisplatinDosetaksel ve Cisplatin- Gemsitabin kombinasyonu arasında Cisplatin - Dosetaksel lehine istatistiksel olarak anlamlı bir üstünlük saptanmıştır.

Tablo-1. İlk Seri Kemoterapi Uygulamaları

\begin{tabular}{|l|l|l|}
\hline İlk seri kemoterapi tipi & $\begin{array}{l}\text { Say1 } \\
(\mathrm{n})\end{array}$ & $\begin{array}{l}\text { Yüzde } \\
(\%)\end{array}$ \\
\hline Cisplatin+Etoposid & 15 & 5 \\
Cisplatin+Gemsitabin & 132 & 44 \\
Cisplatin+Dosetaksel & 60 & 20 \\
Taksotere+Carboplatin & 25 & 8,3 \\
Cisplatin+Vinorelbine & 18 & 6 \\
Vinorelbine & 12 & 4 \\
Dosetaksel & 8 & 2,7 \\
Carboplatin+Gemsitabin & 14 & 4,7 \\
Carboplatin & 1 &, 3 \\
Paklitaksel+Carboplatin & 12 & 4 \\
Erlotinib & 1 &, 3 \\
Pemetrexed & 1 &, 3 \\
Gemsitabin & 1 &, 3 \\
Toplam & 300 & 100 \\
\hline
\end{tabular}

Tablo-2. İlk Seri Kemoterapi Sonrası Oluşan Radyolojik Yanit

\begin{tabular}{|l|l|l|}
\hline $\begin{array}{l}\text { İlk kemoterapi } \\
\text { sonrası oluşan } \\
\text { radyolojik yanıt }\end{array}$ & $\begin{array}{l}\text { Frekans } \\
(\mathrm{n})\end{array}$ & Yüzde (\%) \\
\hline Stabil Hastalık & 82 & 27,3 \\
Progresyon & 136 & 45,3 \\
Değerlendirilemiyor & 51 & 17 \\
Kismi Yanıt & 29 & 9,7 \\
Tam Yanıt & 2 &, 7 \\
Toplam & 300 & 100 \\
\hline
\end{tabular}


Tablo-3. İkinci Seride Kullanılan Kemoterapi

\begin{tabular}{|l|l|l|}
\hline $\begin{array}{l}\text { İkinci seride kullanılan } \\
\text { kemoterapi }\end{array}$ & $\begin{array}{l}\text { Say1 } \\
(\mathrm{n})\end{array}$ & $(\%)$ \\
\hline Almayan & 174 & 58,0 \\
Carboplatin & 2 & 7 \\
Vinorelbine & 23 & 7,7 \\
Karboplatin+Gemsitabin & 3 & 1,0 \\
Cisplatin+Gemzar & 10 & 3,3 \\
Gemsitabin & 5 & 1,7 \\
Cisplatin+Etoposide & 3 & 1,0 \\
Dosetaksel & 53 & 17,7 \\
Taksotere+Karboplatin & 5 & 1,7 \\
Carboplatin+Navelbine & 1 &, 3 \\
Taksotere+Cisplatin & 3 & 1,0 \\
Pemetrexed & 5 & 1,7 \\
Topotekan & 1 & 3 \\
Erlotinib & 10 & 3,3 \\
Cisplatin+Vinorelbin & 1 & 3 \\
Karboplatin+Paklitaksel & 1 & 3 \\
Toplam & 300 & 100,0 \\
\hline
\end{tabular}

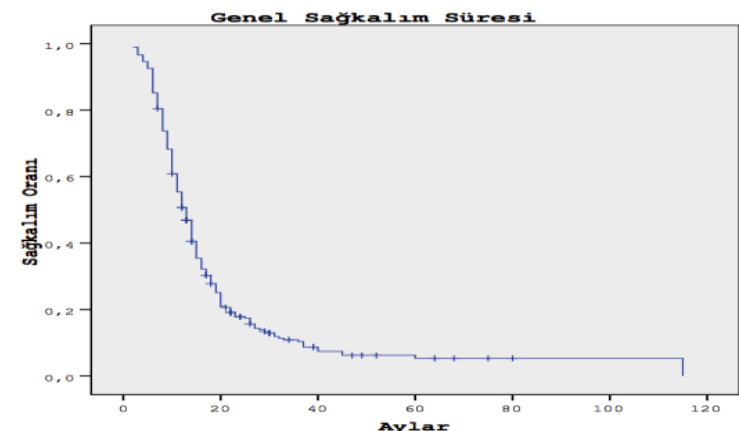

Grafik 4: Histolojik Alt Tiplere Göre Progresyona Kadar Geçen Süre

\section{TARTIŞMA}

Metastatik KHDAK'de benzer etkinlikteki birinci seri kemoterapi kombinasyonunu belirlemede histolojik tip ayrımı yapılmaz iken son yıllarda yapılan çalışmalarda KHDAK tanısı almış olgularda histolojik alt tipin ve moleküler özelliklerinin bilinmesinin uygulanacak sistemik tedavinin secilmesi ve prognoz açısından önemi olduğu saptanmıştır (5). EGFR ve ALK-EML4 mutasyonu gibi erlotinib, gefitinib ve crizotinib gibi tirozin kinaz inhibitörleri için prediktif özelliği olan mutasyonların belirlenmesinin yanı sıra son y1llarda yapılan klinik faz III çalışmalarda platinin yanında kombine edilen ajanın histolojik alt tipin adenokarsinom veya skuamöz histolojide olmasina göre etkinlikte farklılık gösterebileceği saptanmıştır $(6,7)$.

Scagliotti ve arkadaşlarının Cisplatingemsitabin ile Cisplatin-pemetrexed kombinasyonlarının karşılaştırıldığ

Grafik 2: Histolojik Alt Tiplere Göre Genel Sağkalım 
çalışmasında skuamöz hücre histolojili hastalarda Cisplatin-Gemsitabin (genel sağkalım 10.8'e karşın 10.4ay; $\mathrm{p}=0.05$ ) skuamöz dışı histolojilerde ise Cisplatinpemetrexed kombinasyonu daha etkin bulunmuştur (genel sağkalım11.8'e karşın 10.4 ay $\mathrm{p}=0.005) \mathrm{Bu}$ farklılı̆ğn skuamöz hücreli akciğer kanserlerinde saptanan timidilat sentetaz enziminin aşırı ekspresyonunun pemetrexed duyarlılığını azaltmasından kaynaklandığı düşünülmektedir $(8,9,10)$. Çalışmamızın amacı metastatik KHDAK olgularında birinci seride kullanılan kemoterapi rejimlerinin tüm olgularda ve farkl1 histolojik alt tiplerde etkinliğini değerlendirmektir. Çalışmamızda 2005 ve 2010 yıllar1 arasındaki takip edilen KHDAK olgularının tedavi uygulamaları değerlendirilmiştir. $\mathrm{Bu}$ dönemde Cisplatinpemetrexed kombinasyonu ülkemizde geri ödeme kapsamında olmadığ 1 için çalışmamızda bu kombinasyonun birinci seri tedavideki etkinliği değerlendirilememiştir. Birinci seri tedavide kullanılan ilaçlar 5 ana grup altında toplanarak istatistiksel değerlendirmeler yapılmıştır. $\mathrm{Bu}$ gruplar CisplatinEtoposid,Cisplatin-Gemsitabin, CisplatinDosetaksel, Carboplatin-Taksan ve CisplatinVinorelbin'dir.

Birçok farklı yayında skuamöz hücreli karsinom ve adenokarsinomun en s1k görülen tipler olduğu bildirilmiştir. Bizim çalışmamızda incelenen hastalardaki en sık görülen histolojik tip adenokarsinom iken (\%53), ikinci sırada skuamoz hücreli karsinom (\%25.3) geliyordu. ECOG, JCOG9304, JBR 10, CALGB9633 çalışmalarında adenokarsinomlu vakalar çoğunluğu oluşturuyordu. ALPI, IALT, BLT, ANITA ve LACE çalışmalarında ise histolojik alt tip dağılımında skuamöz hücreli karsinom ilk sıradaydı (11,12). Ülkemizde diğer batı ülkelerindekinden farklı olarak halen skuamöz histolojili akciğer kanserlerine daha çok rastlanmaktadır. Adenokarsinomların sıklığ 1 ise artmaktadır. Çalışmamızda adenokarsinom histolojisinin fazla saptanmasinda adenokarsinomların daha erken metastatik hale gelmesi ve alt tipi belirlenemeyen grubun oranının (\%14.3) yükssek olması rol oynamış olabilir. Çalışmamızda tüm olguların genel sağkalım süresi ortanca 13ay \pm 0.6 (GA: 11.914.2 ) olarak saptanmıştır. Histolojik alt tipler ve cinsiyet açısından değerlendirildiğinde genel sağkalım süreleri açısından farklı gruplar arasında istatistiksel olarak anlamlı bir fark saptanmamıştır. Birinci seride kullanılan tedavilerin etkisini metastatik hasta grubunda genel sağkalım sonuçları ile değerlendirmek çok sağlıklı değildir çünkü hastaların büyük bir oranı çok heterojen ikinci ve üçüncü seri tedaviler almıştır. $\mathrm{Bu}$ tedavilerin genel sağkalım sürelerini etkileyeceği göz önüne alınarak çalışmamızda tedavi etkinliği tedavi yanıtından progresyona kadar geçen süre hesaplanarak belirlenmiştir. Birinci seri kemoterapi sonrası progresyona kadar geçen süre ise tüm olgular için ortanca $5 \pm 0$.3hafta (GA:4.5-5.5 ) olarak saptanmıştır. Tüm histopatolojik tipler açısından progresyona kadar geçen süreler değerlendirildiğinde birinci seride kullanılan beş temel ilaç grubu arasında birbirleri ile karşılaştırma yapıldığında Cisplatin-Dosetaksel kombinasyonu ile Cisplatin-Gemsitabin kombinasyonu arasındaki fark istatistiksel olarak anlaml bulundu $(\mathrm{p}=0.029)$ Progresyona kadar geçen süre Cisplatin-Gemsitabin için $6.0 \pm 0.5$ hafta (GA:5.1-7.0), Cisplatin-Dosetaksel için 8.7 \pm 1 .3hafta (GA:6.2-11.2) olarak saptand1. Histolojik alt tiplere göre değerlendirme iki ana grubu oluşturan adenokarsinom ve skuamöz hücreli karsinom alt grupları dışındaki diğer alt gruplara düşen olgu sayıları yeterli olmadığından sadece adenokarsinom ve skuamöz hücreli karsinomlar için yapılabildi. Skuamöz hücreli kanserleri olan olgularda birinci seride kullanılan 5 ana kemoterapi kombinasyonu için progresyona geçen süre açısından istatistiksel olarak bir üstünlük saptanmadi. Adenokarsinom histolojili olgularda ise yine Cisplatin-Dosetaksel kombinasyonunun Cisplatin-Gemsitabin kombinasyonuna göre progresyona kadar geçen süre açısından istatistiksel olarak anlamlı bulunan bir üstünlük sağladığ 1 saptand1 $(\mathrm{p}=0.049)$.Tüm histolojik alt tiplerde saptanan aynı üstünlüğün adenokarsinom alt tipindeki etkisinden kaynaklanabileceği düşünüldü. Çalışmamızda birinci seride en fazla kullanılan kombinasyonların CisplatinGemsitabin (\%44) ve Cisplatin- Dosetaksel (\%20) kombinasyonları olduğu görülmektedir. Tedavi rejimlerinin etkinliğini gruplar arasında kıyaslarken sadece bu iki grup arasındaki fark istatistiksel olarak anlamlı bulunmuştur. Diğer gruplara düşen olgu sayılarının göreceli azlığ 1 küçük farkl1lıkların istatistiksel anlamlılığa 
ulaşmamasına sebep olmuş olabilir. Çalışmamızın retrospektif olması, her kemoterapi grubuna düşen olgu sayısının eşit olmaması nedeniyle diğer kemoterapi grupları arasındaki olası farklılıkları değerlendirmekte yetersiz kalmasına neden olmuş olabilir. Çalışmamızda sonuç olarak birinci seride kullanılan kemoterapi kombinasyonları açısından Cisplatin-Dosetaksel kombinasyonu progresyona kadar geçen süre açısından Cisplatin-Gemsitabin kombinasyonuna göre üstün bulunmuştur. $\mathrm{Bu}$ üstünlüğün özellikle adenokarsinom alt tipindeki etkinliğinin fazla olmasından kaynaklandığı düşünülmektedir. Retrospektif dahi olsa 300 olguda merkezimin klinik tecrübesini yansitan bu sonuçlar KHDAK'nin birinci seri tedavisinde adenokarsinom alt tipinde Cisplatin-Dosetaksel kombinasyonunun etkin olduğunu ve tolerabilitesi mutlaka göz önünde bulundurularak tercih edilebileceğini düşündürtmektedir. Günümüzde NCCN klavuzunun skuamöz dişı histolojilerde birinci seride önerdiği Cisplatin-pemetrexed kombinasyonu çalışmamızda değerlendirilememiştir $(13,14)$.

\section{REFERANSLAR}

1. Bray F, Ferlay J, Soerjomataram I, et al. Global Cancer Sytatistics 2018: GLOBOCAN estimates of incidence and mortality worldwide for 36 cancers in 185 countries. CA Cancer J Clin 2018; 68(6): 394-424.

2. National Comprehensive Cancer Network. Nonsmall cell lung cancer. Available at: http://www.nccn.org/professionals/physician gls/pdf/nscl.pdf 2019 version 4.

3. Planchard D, Popat S, Kerr K, et al. Metastatic nonsmall cell lung cancer: ESMO Clinical Practice Guidelines for diagnosis, treatment and follow- up. Ann Oncol 2018; 29 (Supplement 4): iv192-iv237.

4. U.S. Food and Drug Administration: FDA approves pembrolizumab in combination with chemotheraphy for first-line treatment of metastatic squamous NSCLC. Available at www.fda.gov/Drugs/InformationsOnDrugs/ucm624 659.htm.Accessed January 7, 2019.

5. Schiller JH, Harrington $\mathrm{D}$, Belani $\mathrm{CP}$, et al. Comparison of four chemotherapy regimens for advanced non-small-cell lung cancer. N Engl J Med. 2002;346:92-9
6. NSCLC Meta-Analyses Collaborative Group 2008. Chemotherapy in addition to supportive care improves survival in advanced non-small-cell lung cancer: a systemic review and meta-analysis of individual patient data from 16 randomized controlled trials. J Clin Oncol. 2008;26:4617-4625

7. Giaccone G, Splinter TA, Debruyne C, et al. Randomized study of paclitaxel-cisplatin vs cisplatin-teniposide in patients with advanced nonsmall-cell lung cancer. J Clin Oncol. 1998;16:2133214)

8. Scagliotti GV, De Marinis F, Rinaldi $M$, et al. Phase III randomized trial comparing three platinum-based doublets in advanced non-smallcell lung cancer. J Clin Oncol. 2002;20:4285-4291.

9. Scagliotti GV, Parikh P, von Pawel J, et al. Phase III study comparing cisplatin plus gemcitabine with cisplatin plus pemetrexed in chemotherapy-naive patients with advanced-stage non-small-cell lung cancer. J Clin Oncol. 2008;26:3543-3551).

10. Scagliotti GV,Fossati R, Torri V et al. Adjuvant Lung Protect Italy/European Organisation for Research and Treatment of Cancer-Lung Cancer Cooperative Group Investigators. Randomised Study of Adjuvant Chemoterapy for Completely Resected Stage I,II, or IIIA Non-small Cell Lung Cancer .J Natl Cancer Inst 2003;95:1453-61

11. Schiller JH, Harrington $D$, Belani $C P$, et al. Comparison of four chemotherapy regimens for advanced non-small-cell lung cancer. N Engl J Med. 2002;346:92-98

12. Kelly K, Crowley J, Bunn PA Jr, et al. Randomized phase III trial of paclitaxel plus carboplatin vs vinorelbine plus cisplatin in the treatment of patients with advanced non-small-cell lung cancer: a Southwest Oncology Group trial. J Clin Oncol. 2001;19:3210-3218

13. Douillard JY,Rosell R,De Lena M,et al.Adjuvant Vinorelbine Plus Cisplatin Versus Observation in Patients With Completely Resected Stage IB-IIIA Non-small Cell Lung Cancer (Adjuvant Navelbine International Trialist Association [ANITA]):A Randomised controlled trial. Lancet 2006;7:719727.

14. National Comprehensive Cancer Network (NCCN) Clinical Practical Guidelines in Oncology (NCCN Guidelines ) Non-Small Cell Lung Cancer Version 32012 (www.nccn.com). 